\title{
Europe without Borders: Environmental and Global History in a World after Continents
}

\author{
Alison Frank Johnson \\ Department of History, Harvard University, Cambridge, MA 02138, United States \\ afrank@fas.harvard.edu
}

In 2012 the historian Julia Adeney Thomas restrained her temper but unleashed a warning. The occasion was a forum in the American Historical Review on 'historiographic "turns" in critical perspective'. The perspectives offered were critical enough, Thomas wrote in praise of the other authors, but the forum had a blind spot: 'alongside the turns analyzed here, a world-altering force has been emerging, one larger, more devastating, and more definitive even than "contemporary flexible forms of capitalism": I speak of climate change - or climate collapse - and all of its related global transformations'. Since then, some intersectional scholars have gone beyond that to argue that climate collapse and racial capitalism are not separate topics at all, but are bound together by white supremacy and lingering forms of European imperialism. ${ }^{2}$ Over the past decade some environmental historians have grappled with these connections and deployed new frameworks for thinking about scale, the interdependence of the local and the global, the implications of a Euro-centric analytical framework for our understanding of the world and the relationship between economic systems and environmental change. Although they have developed separately, both environmental history and global history have called upon historians of Europe to rethink boundary making in their methodologies and in their categories of analysis. In an era of global climate catastrophe, global pandemic and global economic crisis, where does the 'European' environment end?

In an attempt to answer this complex question, I will trace the ways that European environmental history has developed in relation to global history, drawing attention to the complex entanglements

1 Julia Adeney Thomas, 'Comment: Not Yet Far Enough', American Historical Review, 117, 3 (2012), 801. Lightly redacted.

2 Carmen Gonzalez, 'Racial Capitalism, Climate Justice, and Climate Displacement', Oñati Socio-legal Series (6 Nov. 2020); Catherine Jampel, 'Intersections of Disability Justice, Racial Justice and Environmental Justice', Environmental Sociology, 4, 1 (2018), 122-35; Kishi Animashaun Ducre, 'The Black Feminist Spatial Imagination and an Intersectional Environmental Justice', Environmental Sociology, 4, 1 (2018), 22-35; Judith Carney, 'Subsistence in the Plantationocene: Dooryard Gardens, Agrobiodiversity, and the Subaltern Economies of Slavery', The Journal of Peasant Studies (2020), 1-25. See also Walter Johnson's argument that 'over and against many recent efforts which assert that a forthright treatment of global environmental history requires the elevation of the categories of the "human" and the "Anthropocene" over and against other historical categories - principally those of race, class, gender, and colonialism [histories of racial capitalism insist] upon the intimate and dialectical relationship between domination and dominion'. Walter Johnson, 'To Remake the World: Slavery, Racial Capitalism, and Justice', The Boston Review (Winter 2017), 30-1. For an older example set within the US context, see Clyde Woods, Development Arrested: The Blues and Plantation Power in the Mississippi Delta. Haymarket Series (London: Verso, 1998) and Alison Isenberg, Charles Connerly, George Lipsitz, Bobby Wilson and June Thomas, 'Symposium on Woods's Development Arrested', Journal of Planning History, 3, 3 (2004), 241-55. There has been a burst of interest in the 'plantationocene'. See, for example, Donna Haraway, 'Anthropocene, Capitalocene, Plantationocene, Chthulucene: Making Kin', Environmental Humanities, 6, 1 (2015), 159-65; Michael Murphy and Caitlin Schroering, 'Refiguring the Plantationocene', Journal of World-Systems Research, 26, 2 (2020), 400-15; Janae Davis, Alex Moulton, Levi Van Sant and Brian Williams, 'Anthropocene, Capitalocene, ... Plantationocene?: A Manifesto for Ecological Justice in an Age of Global Crises', Geography Compass, 13, 5 (2019), 1-15; Nicholas Mirzoeff, 'It's not the Anthropocene, It's the White Supremacy Scene, or, the Geological Color Line', in Richard Grusin, ed., After Extinction (Minneapolis: University of Minnesota Press, 2018), 123-50.

(c) The Author(s), 2021. Published by Cambridge University Press 
between questions of scale and the relevance of national, social and economic categories. These scholarly legacies and innovations have shaped a distinct European environmental history that is at once bound to Europe's history of colonialism and global questions, while it simultaneously reshapes our understandings of European ecosystems and challenges national frameworks for doing history. European environmental history predates the explosion of global history, but both approaches offer productive challenges to the organisation of historical scholarship around the nation state.

The potential for environmental history to be placed in a global context does not render smaller-scale studies of European environments less important. The two are intimately bound together. Understanding the migration patterns and processes of walruses and reindeer in the Arctic has the capacity, as Bathsheba Demuth has demonstrated, to change the ways we think about such grand historical narratives as what makes a capitalist or socialist citizen and how the forces of global capitalism transformed the lives of indigenous peoples. ${ }^{3}$ Environmental history offers 'seemingly built-in globality', as Sebastian Conrad notes: 'the effects of soil erosion, earthquakes, and tsunamis, as well as the spread of germs and pathogens, diseases and epidemics, and so forth, plainly require perspectives that are open to spaces constituted by the object of study, which do not necessarily converge with national and imperial borders'. ${ }^{4}$ Opening one's eyes to ecological considerations can make even the most seemingly parochial concerns get very global very quickly, as David Harvey learned during a dispute with a co-editor about how to frame the conclusion to a book about the Oxford Motor Industry Research Project. ${ }^{5}$ A story that began with a conflict between management, union leadership and workers at one Rover car plant in southeastern England soon revealed the limitations inherent in ignoring the conflict's global context: 'I found myself arguing for at least a European-wide perspective on adjustments in automobile production capacity, but found it hard to justify stopping at that scale when pressed. There were also important ecological issues to be considered deriving not only from the plant itself (the paint shop was a notorious pollution source) but also from the nature of the product. Making Rover cars for the ultra-rich and so contributing to ecological degradation hardly seemed a worthy long-term socialist objective. ${ }^{6}$ When Harvey placed an initially local labour story in a larger global scale, he found new arguments about impact and exploitation that raised the spectre of

3 Bathsheba Demuth, Floating Coast: An Environmental History of the Bering Strait (New York: Norton, 2019) and 'The Walrus and the Bureaucrat: Energy, Ecology, and Making the State in the Russian and American Arctic, 1870-1950', The American Historical Review, 124, 2 (2019), 483-510.

4 Sebastian Conrad, What is Global History? (Princeton, NJ: Princeton University Press, 2016), 116-. Recent examples of Anglophone global environmental history include John McNeill, Something New Under the Sun: An Environmental History of the Twentieth Century (New York: Norton, 2000); Joachim Radkau, Nature and Power: A Global History of the Environment, translated T. Dunlap (New York: Cambridge University Press, 2008); William Beinart and Lotte Hughes, Environment and Empire (Oxford University Press: Oxford, 2007); John Richards, The Unending Frontier: The Environmental History of the Early Modern World (Berkeley: University of California Press, 2003); Shepard Krech, John R. McNeill and Carolyn Merchant, Encyclopedia of World Environmental History (New York: Routledge, 2004); J. Donald Hughes, An Environmental History of the World: Humankind's Changing Role in the Community of Life (New York: Routledge, 2001); Edmund Burke III and Kenneth Pomeranz, eds., The Environment and World History (Berkeley: University of California Press, 2009); Corinna Unger and John McNeill, eds., Environmental Histories of the Cold War (New York: Cambridge University Press, 2010); Sabine Hoehler, Spaceship Earth in the Environmental Age, 1960-1990, $2^{\text {nd }}$ edition (New York: Routledge, 2016) and Rob Nixon, Slow Violence and the Environmentalism of the Poor (Cambridge, Mass.: Harvard University Press, 2011). See also Donald Hughes, What is Environmental History (New York: Polity, 2006) and J. R. McNeill, 'The State of the Field of Environmental History', Annual Review of Environment and Resources, 35 (2010), 345-74.

5 Teresa Hayter and David Harvey, eds., The Factory and the City: The Story of the Cowley Auto Workers in Oxford (London: Mansell, 1993). The dispute is described in David Harvey, Justice, Nature, and the Geography of Difference (Oxford: Blackwell, 1996), 19-23.

6 Harvey, Justice, 22. 
concentric circles of privilege - concerns that lurk in the shadows of European histories that do not acknowledge global contexts.

This issue of scale was raised by Alfred Crosby in an essay on the 'The Past and the Present of Environmental History' in 1995. ${ }^{7}$ According to Crosby, American historians' lack of 'burning interest' in environmental history until after the Second World War was not from lack of subject matter. From Krakatoa and the ensuing tsunami, which killed 40,000 in 1893, to the explosion of a comet in Siberia that 'flattened 2,000 square kilometers of forest' in 1908, to the devastating importation of rinderpest into sub-Saharan Africa, to multiple species extinctions, the overrunning of Australia with sheep, the overpopulation of the planet with humans, deforestation, urbanisation, pollution: Crosby showed that the period from 1875 to 1945 was rife with opportunities to engage the changing physical environment on a scale that dwarfed national concerns. Crosby's goal was to sketch the genealogy of post-war US environmental history, which he traces to a combination of the Annales school and French geography, the spectre of nearly unlimited US military power during the Cold War, the moon landing and, finally, the environmental movement. ${ }^{8}$ More interesting to me, however, are the multiplicity of scales that Crosby used to set the stage for this story of first neglect and then attention. In the first three pages of his essay, Crosby mentioned Cleveland, Krakatoa, Siberia, Sub-Saharan Africa, the Horn of Africa, Somalia, the Cape Colony, Amsterdam, Cincinnati, Ohio, North America, Australia, Europe, the United States, Brazil, the Atlantic, the Great Lakes, the northeastern United States, Great Britain's Midlands, the Ruhr Valley, Buenos Aires and Chicago. ${ }^{9}$ Crosby's broad geographic coverage (which inexplicably overlooked Asia) relied on examples from the microscopic to the continental. His spatial units included cities, countries (and the occasional nation state), regions, oceans, one single volcano and an island-continent. His agents and actors included viruses (influenza, rinderpest), celestial objects (comets), seismic events (tsunami), humans (Africans, Italians, Bernard Bailyn, riverine populations, nomads, Teddy Roosevelt, Gifford Pinchot), other animals (cattle, wild ungulates, quagga, buffalo, sheep, guanaco, kangaroo, antelope, ostrich, emu, rhea, marsupials, placental animals) and one specific bird (Martha, the world's last passenger pigeon). From the global population to the 1.3 million Europeans who 'steamed' to the United States in 1907 ('more living biomass than had ever crossed an ocean in such a short time') to single individuals, from specific places (the Cincinnati zoo) to types of ecological spaces (grasslands, forests, rivers), to the planet itself: nothing was too large or too small for Crosby's attention. In this, if nothing else, he was like Franz I, the first selfproclaimed emperor of Austria, who is credited with saying 'there is no affair that a priori and according to general principles could be called large or small; matters are only large or small in comparison to and in relation to other things. ${ }^{10}$

Neither global nor environmental history need be planetary in scale, but historians do have to be self-conscious in choosing scales. ${ }^{11}$ Deborah Coen's recent book on climate science historicises the concept of working across scales, locating its emergence in the unlikely halls of Habsburg

\footnotetext{
7 Alfred Crosby, 'The Past and Present of Environmental History', American Historical Review, 100, 4 (Oct. 1995), $1177-89$.

8 Crosby, "Past and Present," 1185-6.

9 Ibid., 1177-9.

10 Quoted in Deborah Coen, Climate in Motion: Science, Empire, and the Problem of Scale (Chicago: University of Chicago Press, 2018), 16.

11 See Julia Adeney Thomas, 'History and Biology in the Anthropocene: Problems of Scale, Problems of Value', American Historical Review, 119, 5 (2014), 1587-1607. Steven Press begins his investigation of 'rogue empires' in the Scramble for Africa with an individual African-American whistleblower in the Independent State of Congo, spends a chapter in Berlin, but finds the origins of the sovereignty principle that underwrote rogue empires in Africa in Southeast Asia. Steven Press, Rogue Empires: Contracts and Conmen in Europe's Scramble for Africa (Cambridge, Mass.: Harvard University Press, 2017). Sabine Hoehler writes about El Niño as a local weather event with horrific human cost in coastal Pacific states and the El Niño Southern Oscillation as a global climate pattern visible only via remote sensing satellites; see Sabine Hoehler, 'Local Disruption or Global Condition: El Niño as Weather and as Climate Phenomenon', GEO Geography and Environment, 4, 1 (2017), 1-11. On the emergence of planetary thinking, see Benjamin W. Goossen, 'A Benchmark for the Environment: Big Science and 'Artificial' Geophysics in the Global 1950s', Journal of Global History, 15, 1 (2020), 149-68.
} 
climatological science. 'What makes modern climate science modern is its integration of phenomena of radically different dimensions', an integration that requires 'thinking across scales of space and time'. ${ }^{12}$ This way of thinking, according to Coen, came naturally to an empire self-consciously composed of a patchwork of larger and smaller territories, with their own political histories, legal practices and even climates. ${ }^{13}$ But thinking within nations has been a hard habit to break - and that is one of the advantages of both global and environmental history, which Sebastian Conrad has suggested leads historians to 'break out of all established spatial units, including empires, religions, and civilizations.' ${ }^{14}$ Although this suggests an attack on all spatial units, 'venerable Eurocentric spatialities', most especially nation states, inspire global history's most ardently 'polemical dimension'. ${ }^{15}$ One of the problems that inspired global history in the first place is the too long, too frequent and too unthinking precedence of European perspectives. Europe does not occupy a neutral place in global history. Kären Wigen and Martin Lewis argue, for example, that one of the advantages of investigating 'world regions' instead of 'continents' was that it would 'demote Europe to its proper place'. ${ }^{16}$ Even understanding the Global North's outsized role in creating (and exporting) the capitalist underpinnings of environmental crisis requires paying attention to the costs of climate change paid across the Global South. Global environmental history often speaks to the history of Europe and Europeans - the foods Europeans eat, the clothing they wear, the aftereffects of their ideological, military, and material exports. ${ }^{17}$ Dipesh Chakrabarty has suggested that if the connection between European and global history was once based on imperialists 'exporting the border-form outside Europe', it now comes from the 'new subalterns of the global economy - refugees, asylum seekers, illegal workers' who 'can be found all over Europe' for reasons embedded in both environment and economy. 'Do not one billion human beings already live without access to proper drinking water?' he asks with anguish. ${ }^{18}$

Long before Chakrabarty, W.E.B. DuBois had keened over the human and animal lives lost in Africa to feed European empires. This is a long quotation, but I assure you it is worth reading every word of DuBois's description of the 'capitalist exploitation' of Africa:

where the right hand knew nothing of what the left hand did, yet rhymed its grip with uncanny timeliness; where the investor neither knew, nor inquired, nor greatly cared about the sources of his profits; where the enslaved or dead or half-paid worker never saw nor dreamed of the value of his work (now owned by others); where neither the society darling nor the great artist saw the blood on the piano keys; where the clubman, boasting of great game hunting, heard above the

12 Coen, Climate in Motion, 2. On European and global climate, see Wolfgang Behringer, A Cultural History of Climate (Cambridge: Polity, 2010) first published as Kulturgeschichte des Klimas in 2007; Wolfgang Behringer, Tambora und das Jahr ohne Sommer (Munich: Beck, 2015); William Klingaman and Nicholas Klingaman, The Year Without Summer: 1816 and the Volcano that Darkened the World and Changed History (New York: St. Martin's Griffin, 2013); Le Roy Ladurie, Histoire humaine et comparée du climat 3 volumes (Paris: Fayard, 2004-2009); James Fleming, Vladimir Jankovic and Deborah Coen, eds., Intimate Universality: Local and Global Themes in the History of Weather and Climate (Sagamore Beach, Mass.: Science History Publications, 2006); Dagomar Degroot, The Frigid Golden Age: Climate Change, the Little Ice Age, and the Dutch Republic, 1560-1720 (Cambridge: Cambridge University Press, 2018). A pan-European example is Brian Fagan, The Little Ice Age: How Climate Made History 1300-1850 (New York: Basic, 2000). See also Martin Mahony and Georgina Endfield, 'Climate and Colonialism', Wiley Interdisciplinary Reviews: Climate Change, 9, 2 (2018), E510.

13 Pairing Sam White, The Climate of Rebellion in the Early Modern Ottoman Empire (Cambridge: Cambridge University Press, 2001) and Geoffrey Parker, Global Crisis: War, Climate Change and Catastrophe in the Seventeenth Century (New Haven: Yale University Press, 2014) produces a similar effect.

14 Conrad, What is Global History?, 116.

15 Ibid., on spatialities, 116, and on polemical dimension, 4.

16 Martin Lewis and Kären Wigen, The Myth of Continents: A Critique of Metageography (Berkeley: University of California Press, 1997), 13.

17 For an argument that global climate patterns are connected to European intellectual history, see Michael Davis, Late Victorian Holocausts El Niño Famines and the Making of the Third World (London: Verso, 2001).

18 Dipesh Chakrabarty, 'Postcolonial Studies and the Challenge of Climate Change', New Literary History, 43, 1 (Winter 2012), 7. 
click of his smooth, lovely, resilient billiard balls no echo of the wild shrieks of pain from kindly, half-human beasts as fifty to seventy-five thousand each year were slaughtered in cold, cruel, lingering horror of living death; sending their teeth to adorn civilization on the bowed heads and chained feet of thirty thousand black slaves, leaving behind more than a hundred thousand corpses in broken, flaming homes. ${ }^{19}$

DuBois related imperial subordination - the instrumentalisation of human beings - to ecological subordination - the extraction of natural resources and, in some cases, the extinction or near-extinction of non-human animal species. ${ }^{20}$ In his extensive (and sometimes manic) 1895 diary entries, Theodor Herzl noted a now infamous plan to have 'natives' of whatever future territory the Jewish people might settle clear the land of dangerous beasts like 'big snakes' - a comment that echoes the kind of Rhodesian fantasy of white mastery that DuBois critiques. ${ }^{21}$ Even the best local European environmental histories inevitably miss the scale of violence that underwrites Europeans' material comfort if they eschew its global context. Thus, as European histories reckon with legacies of racial capitalism and the many-sided traumas associated with colonialism and its afterlife, histories of Europe itself have begun to change. ${ }^{22}$

This is clearly visible in new histories of Europe that explore racial capitalism, environmental change and cultural and social interactions both across and within continents. Wherever the history of capitalism is invoked, environmental history cannot be ignored. As a historian of the British Empire, John MacKenzie had embraced a global scale in his earliest publications on the popular culture of imperialism. He turned to environmental history in his 1988 monograph, The Empire of Nature, on the role of hunting and conservation in British imperial rule in Africa and India. ${ }^{23}$ 'Africa', explained MacKenzie in a later autobiographical note, 'had been conquered on the back of its animals' not only because of commodity trades (see, again, DuBois) but because of the protein that hunting offered European settlers and the railway workers who built their empires. Having created animal scarcity, European settlers then transformed themselves into the protectors of African animals and transformed African hunters into poachers. ${ }^{24}$ MacKenzie later published a lecture series intentionally calling up the earlier monograph's title, Empires of Nature and the Nature of Empires. Scotland was an example of a peripheral territory (within the United Kingdom) whose environment had been manipulated (by sheep, by the heather spread in order to make the moors more attractive to the grouse that tourists so loved to shoot), while Scots were effective participants in the reshaping of

19 W.E.B. Du Bois, The World and Africa: An Inquiry into the Part Which Africa Has Played in World History (New York: Viking, 1947), 74.

20 Walter Johnson, 'To Remake the World'.

21 For a nuanced analysis of how Theodor Herzl's diary entries reflect on his colonialist plans for settlement and the use of indigenous peoples to remove 'wild animals', see Derek Penslar, 'Herzl and the Palestinian Arabs: Myth and Counter-Myth', Journal of Israeli History, 24, 1 (2005), especially pages 70-2. On his attitude toward colonialism more broadly, see Derek Penslar, Theodor Herzl: The Charismatic Leader (New Haven: Yale University Press, 2020), 137-40. In this beautiful biography, Penslar describes Herzl's diary entries from the Summer of 1895 as 'enthralling and illuminating, yet also unnerving and disturbing. They contain flashes of paranoia and of prescient wisdom, megalomania and altruistic idealism, delusions of grandeur and canny self-awareness'. Penslar, Herzl, 74.

22 See, for example, analysis of the history of medicine and migration in interwar Paris: Clifford D. Rosenberg, Policing Paris: The Origins of Modern Immigration Control between the Wars (Ithaca: Cornell University Press, 2006).

23 John MacKenzie, The Empire of Nature: Hunting, Conservation, and British Imperialism (Manchester: Manchester University Press, 1988).

24 John MacKenzie, 'A Meditation on Environmental History', in Karl Hele, ed., The Nature of Empires and the Empires of Nature: Indigenous Peoples and the Great Lakes Environment (Waterloo, 2013), 2-3, 5-6. This calls to mind a now classic work elaborating Europe's responsibility for not 'civilising', but rather underdeveloping Africa: Walter Rodney, How Europe Underdeveloped Africa (Washington, DC: Howard University Press, 1974). Numerous citations on literature detailing the connections between European imperialism and anti-slavery can be found in Alison Frank, 'The Children of the Desert and the Laws of the Sea: Austria, Great Britain, the Ottoman Empire, and the Mediterranean Slave Trade in the Nineteenth Century', The American Historical Review, 117, 2 (2012), 410-44. 
environments all over the world. Younger scholars inspired by MacKenzie have traced the work of those Scottish emigrants in the Great Lakes region and analysed it from the perspective of Indigenous Studies. ${ }^{25}$

The recognition of the dialectical relationship between European and global history has long characterised environmental history, thanks in no small measure to Crosby himself and his 1972 book, The Columbian Exchange, which made Europeans' immunobiology immediately relevant to the environments and the peoples they encountered in the Americas. ${ }^{26}$ In the 1970s Crosby and William McNeill established what is now a crowded field of historians tracing the movements of people and pathogens across the globe. ${ }^{27}$ Europeans feature prominently in such stories, as do the ectoparasites that travel on their skin, the microscopic organisms that travel in their lungs, their spit, not to mention the rats on their ships. As M. Christopher Low, an Ottoman environmental historian, has uncovered, ideas of medical quarantine, surveillance and sovereignty developed in tandem with one another during the nineteenth century; the threat of disease in a faraway port of the British or Ottoman empire was inseparable from questions of European sovereignty. ${ }^{28}$

Then there are the histories of hunters (so called sportsmen), explorers and naturalists traveling all across the world, of botanists, geologists and meteorologists and their links to the creation and function of empires, natural history museums and human zoos or 'people shows' ${ }^{29}$ Europeans' drive to get further, faster often endangered the lives of people (not to mention animals, plants, and other living organisms) they encountered through conquest and disease, as well as brazen kidnapping. 'The most precious resource' to explorers like Magellan and Drake 'came in human form', writes Joyce Chaplin, who dedicated her 2012 book Round About the Earth to Enrique de Malacca, who was impressed into the role of first man to go around the world. ${ }^{30}$ Explorers, spice traders and the naturalists they towed along moved plants and animals into natural history museums, botanical gardens, zoos and laboratories, not to mention from one colonial territory to another. ${ }^{31}$ Scientists drew the maps and catalogued

25 John MacKenzie, Empires of Nature and the Nature of Empires: Imperialism, Scotland and the Environment: The Callander Lectures (East Linton: Tuckwell, 1997); Hele, Nature of Empires.

26 Alfred Crosby, The Columbian Exchange: Biological and Cultural Consequences of 1492 (Westport, CT: Greenwood Press, 1972).

27 Crosby, Columbian Exchange; William McNeill, Plagues and Peoples (New York: Anchor, 1976) and Alfred Crosby, Ecological Imperialism: The Biological Expansion of Europe, 900-1900 (Cambridge; Cambridge University Press, 1986). On smallpox, see Michael Bennett, War on Smallpox: Edward Jenner and the Global Spread of Vaccination (Cambridge: Cambridge University Press, 2020) and Erez Manela, 'A Pox on Your Narrative: Writing Disease Control into Cold War History', Diplomatic History, 34, 2 (2010), 299-323; on the 1918 flu pandemic, see Alfred W. Crosby, America's Forgotten Pandemic: The Influenza of 1918 (Cambridge: Cambridge University Press, 1989). Crosby noted that the AHA annual conference had to be cancelled in December 1918 but that even this did not result in historical interest in the environmental history of pandemic. By 1939 the AHR had so forgotten the scale of the public health catastrophe that they blamed the cancellation of the conference on the post-war congestion of the railroads. Crosby, 'Past and Present', 1177.

28 Michael Christopher Low, 'Empire and the Hajj: Pilgrims, Plagues, and Pan-Islam under British Surveillance, 1865-1908', International Journal of Middle East Studies, 40, 2 (2008), 269-90; Michael Christopher Low, 'Ottoman Infrastructures of the Saudi Hydro-State: The Technopolitics of Pilgrimage and Potable Water in the Hijaz', Comparative Studies in Society and History, 57, 4 (2015), 942-74; Michael Christopher Low, Imperial Mecca: Ottoman Arabia and the Indian Ocean Hajj, Columbia Studies in International and Global History (New York: Columbia University Press, 2020).

29 In addition to MacKenzie, cited above, see Martin Mahomy, "For an Empire of "All Types of Climate": Meteorology as an Imperial Science', Journal of Historical Geography, 51 (2016), 29-39; Sadia Qureshi, Peoples on Parade: Exhibitions, Empire, and Anthropology in Nineteenth-Century Britain (Chicago: University of Chicago Press, 2011); Helmut Walser Smith, 'Ausstellung des Fremden-Menschen- und Völkerschau um 1900', in Sebastian Conrad and Jürgen Osterhammel, eds., Das Kaiserreich Transnational: Deutschland in der Welt, 1871-1914.

30 Joyce Chaplin, Round About the Earth: Circumnavigation from Magellan to Orbit (New York: Simon \& Schuster, 2012), $38,21,329$.

31 Anya Zilberstein follows wild rice from Canada to Britain, Bohemia and New South Wales. See Anya Zilberstein, 'Inured to Empire: Wild Rice and Climate Change', The William and Mary Quarterly, 72, 1 (2015), 127-58. See also Daniel Kehlmann's novel about Gauss and Humboldt, Die Vermessung der Welt (Reinbek: Rowohlt, 2005). 
the flora and fauna that made imperial conquest possible, even if they also bemoaned the environmental and human consequences of the so-called civilising process. ${ }^{32}$

$\bullet \bullet$

Environmental histories of Europe test the boundaries of the nation state and call attention to other ways of defining space in the histories we write. In no small measure due to a suspicion of the nation state as the 'natural' form of historical analysis, European history has embraced all sorts of supra and sub-national spaces. ${ }^{33}$ Environmental history is a natural ally for attempts to turn away from the nation state as the primary unit of analysis, a project with such ideological force it has been referred to as 'rescuing history from the nation'. ${ }^{34}$ For some historians, environmental approaches offer a vehicle through which they can counter standard assumptions about European politics, ideology and historical spaces. Such is the case in Astrid Eckert's compelling new analysis of the environment and the West German borderlands; Carolin Roeder's work on mountaineering, international cooperation and risk; or, in a provocative way, Timothy Snyder's Black Earth, which boldly sought to resituate the Holocaust in an ecological framework. ${ }^{35}$ For other European historians, like Eagle Glassheim, adopting a local environmental approach has enabled new directions for thinking about marginality and racial capitalism in Europe itself. ${ }^{36}$ As David Blackbourn has noted, an ecological 'unit of enquiry - a watershed, a forest, a desert, the habitat of a particular species - might well be simultaneously subnational and supra-national, confounding national borders in a double sense' ${ }^{37}$ Historians have

32 Joyce Chaplin, 'The Curious Case of Science and Empire', Reviews in American History, 34, 4 (2006), 434-440; Crosby, Ecological Imperialism; Richard Grove, Green Imperialism: Colonial Expansion, Tropical Island Edens and the Origins of Environmentalism, 1600-1860 (Cambridge: Cambridge University Press, 1995); Richard Drayton, Nature's Government: Science, Imperial Britain, and the Improvement of the World (New Haven: Yale University Press, 2000); Margarette Lincoln, Science and Exploration in the Pacific: European Voyages to the Southern Oceans in the Eighteenth Century (Woodbridge: Boydell, 1998); Ryan Tucker Jones, Empire of Extinction: Russians and the North Pacific's Strange Beasts of the Sea, 1741-1867 (Oxford: Oxford University Press, 2014); John Gascoigne, Science in the Service of Empire: Joseph Banks, the British State and the Uses of Science in the Age of Revolution (Cambridge: Cambridge University Press, 1998); Peder Anker, Imperial Ecology: Environmental Order in the British Empire, 1895-1945 (Cambridge: Harvard University Press, 2001). For an example of a work that focuses on the discoveries of enslaved African women and the ways their dissemination to European women was prevented by European men, see Londa Schiebinger, Plants and Empire: Colonial Bioprospecting in the Atlantic World (Cambridge: Harvard University Press, 2004). Aaron Sachs' tries to focus attention on Humboldt's critique of the 'social and ecological damage wrought by colonialism', in The Humboldt Current: Nineteenth-Century Exploration and the Roots of American Environmentalism (New York: Viking, 2006), 13; compare to Mary Louise Pratt, Imperial Eyes: Travel Writing and Transculturation (London: Routledge, 1992).

33 Sverker Sörlin and Paul Warde, 'The Problem of the Problem of Environmental History: A Re-Reading of the Field', Environmental History, 12, 1 (2007), 107-130, especially 108-10. Verena Winiwarter and a team of thirteen co-authors wrote a review of the first decade following the founding of Environment and History. Verena Winiwarter, et al, 'Environmental History in Europe from 1994 to 2004: Enthusiasm and Consolidation', Environment and History, 10, 4 (2004), 501-30.

34 Prasenjit Duara, Rescuing History from the Nation: Questioning Narratives of Modern China (Chicago: University of Chicago Press, 1995); Tara Zahra, 'Imagined Noncommunities: National Indifference as a Category of Analysis', Slavic Review, 69, 1 (2010), 93-119.

35 Astrid M. Eckert, West Germany and the Iron Curtain: Environment, Economy, and Culture in the Borderlands (New York: Oxford University Press, 2019); Carolin Firouzeh Roeder, 'European Mountaineers Between East and West: A Transnational History of Alpinism in the Twentieth Century', PhD Thesis, Harvard University, 2017 and Carolin Roeder, 'From Neo-Slavism to Internationalism: Interwar Central Europe and the Search for the Lost Mountains', Contemporary European History, 29, 1 (2020), 16-29; Timothy Snyder, Black Earth: The Holocaust as History and Warning (New York: Tim Duggan Books, 2015). See also Tait Keller, Apostles of the Alps: Mountaineering and Nation Building in Germany and Austria, 1860-1939 (Chapel Hill: UNC Press Books, 2015) and Andrew Denning, Skiing into Modernity: A Cultural and Environmental History (Oakland: University of California Press, 2015).

36 See, for example, Eagle Glassheim, 'Most, the Town that Moved: Coal, Communists and the "Gypsy Question" in Post-War Czechoslovakia', Environment and History (2007), 447-76.

37 Marco Armiero and Wilko Hardenberg, 'On History, Nature and Nation: An Interview with David Blackbourn', Environment and History, 20 (2014), 146. 
looked at European forests, rivers, deserts and fire; disease, pollution and stink; zoos, pets and animals at war; spas and seismological laboratories. ${ }^{38}$ Even when their titles suggest they are about nation states, these works attend to spaces defined by some sort of ecological logic (a forested region in the Pyrenees or a single forest district in Württemberg or - in the case of my own book, for example, the surface-level political units covering subterranean petroleum reservoirs). ${ }^{39}$ They call up comparisons with distant places and connections forged by people and goods on the move.

The movement of goods - whether oil, ostrich feathers or ivory; sugar, pineapples, glass or cotton can help historians see connections across political spaces. ${ }^{40}$ Europeans have been great consumers of global commodities. Yet Blackbourn highlights that commodity history is one way of recentring European history while acknowledging its larger contexts in a new way: 'the German interior was linked to the slave trade, importing sugar and producing metal goods for exchange in Africa and exporting textiles to clothe plantation slaves' and along with all those traveling people went 'another form of global traffic', non-human this time, sometimes deliberate and sometimes accidental. 'Diseases like cholera that threatened humans, species like the Colorado Beetle and phylloxera that attacked domestic crops, the flora that were emptied out of the ballast tanks of steamships and floated up German waterways - all were signs of the interlinking of Germany with the wider world in ways that deserve more attention from historians, not least because of the light they shed on the environmental challenges we face today'. ${ }^{41}$ Following commodities helps uncover connections that other histories of imperialism might miss. Many of the Germans who 'spread around the world as merchants, missionaries, scientists, foresters, mining engineers, and, of course, military advisers' did so under the flags of other empires. ${ }^{42}$

Placing European history in a global context reopens questions about what Europe is and where it properly ends. Here, too, environmental history offers its own set of challenges. Geographers have never done a particularly good job of defining Europe, a point that has been made before. ${ }^{43}$ There is no such thing as a European environment, no such thing as Europe's nature. Giancarlo Casale

38 Tamara Whited, Forests and Peasant Politics in Modern France (New Haven: Yale University Press, 2000); Paul Warde, Ecology, Economy, and State Formation in Early Modern Germany (Cambridge: Cambridge University Press, 2006); David Blackbourn, The Conquest of Nature: Water, Landscape, and the Making of Modern Germany (New York: Norton, 2006); Philipp Lehmann, 'Changing Climates: Deserts, Desiccation, and the Rise of Climate Engineering, 1870-1950', PhD Thesis, Harvard University, 2014; Steven Pyne, Vestal Fire: An Environmental History, Told Through Fire, of Europe and Europe's Encounter with the World (Seattle: University of Washington Press, 1997); Richard Evans, Death in Hamburg: Society and Politics in the Cholera Years (New York: Penguin, 1990); Frank Snowden, The Conquest of Malaria: Italy 1900-1962 (New Haven: Yale University Press, 2006); Peter Thorsheim, Inventing Pollution: Coal, Smoke, and Culture in Britain since 1800 (Athens: Ohio University Press, 2006); and Alain Corbin, The Foul and the Fragrant: Odor and the French Social Imagination (Cambridge: Harvard University Press, 1986); Nigel Rothfels, Savages and Beasts: The Birth of the Modern Zoo (Baltimore: Johns Hopkins University Press, 2002); Gary Bruce, Through the Lion Gate: A History of the Berlin Zoo (Oxford: Oxford University Press, 2017); Harriet Ritvo, The Animal Estate: The English and Other Creatures in the Victorian Age (Cambridge: Harvard University Press, 1987); John Singleton, 'Britain's Military Use of Horses 1914-1918', Past and Present, 139, 1 (1993), 178-203; Eric Jennings, Curing the Colonizers: Hydrotherapy, Climatology, and French Colonial Spas (Durham, NC: Duke University Press, 2006); and Deborah Coen, The Earthquake Observers: Disaster Science from Lisbon to Richter (Chicago: Chicago University Press, 2013). On river history, see Schönach, 'River Histories: A Thematic Review', Water History, 9, 3 (2017), 233-57.

39 Alison Fleig Frank, Oil Empire: Visions of Prosperity in Austrian Galicia (Cambridge: Harvard University Press, 2005).

40 Sidney Mintz, Sweetness and Power: The Place of Sugar in Modern History (New York: Viking, 1985); Gary Okihiro, Pineapple Culture: A History of the Tropical and Temperate Zones (Berkeley: University of California Press, 2009); Sarah Stein, Plumes: Ostrich Feathers, Jews, and a Lost World of Global Commerce (New Haven: Yale University Press, 2008); Alan Macfarlane, Glass: A World History (Chicago: University of Chicago Press, 2002); Sven Beckert, Empire of Cotton: A Global History (New York: Knopf, 2014).

41 David Blackbourn, 'Nineteenth-Century German History: Dangling in Space?', Central European History, 51, 4 (2018), 620-1.

42 Ibid., 620.

43 Philipp Nielsen, 'What, Where and Why is Europe? Some Answers from Recent Historiography', European History Quarterly, 40, 4 (2010), 701-13. 
has pointed out, with characteristic wit, that the European Age of Exploration is only remarkable because prior to it, Western Europe had been 'totally confined, both physically and intellectually, to a small slice of the world bounded by the North Atlantic and the Mediterranean' at the same time that the Ottomans were sailing towards Indonesia. ${ }^{44}$ Once Europeans 'caught up', so to speak, to this urge to move outward, however, there was no stopping the expansionist drive. Europe has no natural eastern boundary at all and, as its maritime capacities increased, its boundedness to the south, west and north became more an invitation to interaction than a barrier. ${ }^{45}$ The massive field of Atlantic history is too vast to dare even to list leading works in a footnote. ${ }^{46}$ The legacy of Braudel's Mediterranean could rightly form the bulk of this essay, differently approached, all on its own, perhaps with the opening line 'In the beginning, there was the Mediterranean'. ${ }^{47}$ Indeed, Crosby, in his overview of US environmental history, cannot explain how it took over twenty years to translate Mediterranean into English or why Braudel and the Annales school more broadly 'did not initiate the surge of environmental history in America', as he put it. ${ }^{48}$ Europe's conceptual existence relies on ideology, not least imperialist and racialist thinking, rather than simple physical geography.

In recent decades conversations about boundaries and borders have had a vertical dimension as well. When the Soviet Union launched the world's first satellite, Sputnik, into orbit, it drew both the United States and Europe into a panicked race for capacities to occupy and utilise the space 'above' us. Lisa Rand has described the process that followed as the transformation of the area between the atmosphere and the moon into a 'landscape'. ${ }^{49}$ The United States launched surveillance aircraft, including the U2 spy planes, from allied territories including West Germany. ${ }^{50}$ In addition to creating opportunities for conflict (including the military consequences of debates over airspace), there were

44 Giancarlo Casale, The Ottoman Age of Exploration (Oxford: Oxford University Press, 2010), 5.

45 On the artificiality of Europe's boundary with Asia, see Mark Bassin, 'Russian Between Europe and Asia: The Ideological Construction of Geographical Space', Slavic Review, 50, 1 (Spring 1991), 1-17. On the Baltic, see Michael North, The Baltic: A History transl. Kenneth Kronenberg (Cambridge: Harvard University Press, 2015).

46 So I won't. Instead, see David Armitage, 'The Atlantic Ocean', in David Armitage, Alison Bashford and Sujit Sivasundaram, eds., Oceanic Histories (Cambridge: Cambridge University Press, 2018). On Bernard Bailyn's Atlantic and Braudel's Mediterranean, see John Marino, 'The Exile and His Kingdom: The Reception of Braudel's Mediterranean', Journal of Modern History, 76, 3 (2004), 622-52.

47 Molly Greene calls it the 'Ur-sea'. See Molly Greene, 'The Mediterranean Sea', in Armitage, Bashford and Sivasundaram, Oceanic Histories, 134. Michael Herzfeld bemoans the reification of the category 'Mediterranean'. Michael Herzfeld, 'Practical Mediterraneanism: Excuses for Everything, from Epistemology to Eating', in W.V. Harris, ed., Rethinking the Mediterranean (Oxford: Oxford University Press, 2004). See also Peregrine Horden, 'Mediterranean Excuses: Historical Writing on the Mediterranean since Braudel', History and Anthropology, 16, 1 (2005), 25-30; Peregrine Horden and Nicholas Purcell, The Corrupting Sea: A Study of Mediterranean History (Oxford: Blackwell 2000); Alfred Thomas Grove and Oliver Rackham, The Nature of Mediterranean Europe: An Ecological History (New Haven: Yale University Press, 2001); Peregrine Horden and Nicholas Purcell, 'The Mediterranean and "The New Thalassology"', American Historical Review, 111, 3 (2006), 722-40; Faruk Tabak, The Waning of the Mediterranean, 1550-1870: A Geohistorical Approach (Baltimore: Johns Hopkins University Press, 2008); David Abulafia, The Great Sea: A Human History of the Mediterranean (London: Allen Lane, 2011); and David Abulafia, 'Mediterranean History as Global History', History and Theory, 50, 2 (2011), 220-8.

48 A full review of the impact of Braudel is available here: John A. Marino, 'The Exile and His Kingdom: The Reception of Braudel's Mediterranean', The Journal of Modern History, 76, 3 (2004), 622-52.

49 Lisa Ruth Rand, 'Orbital Decay: Space Junk and the Environmental History of Earth's Planetary Borderlands', PhD Thesis, University of Pennsylvania, 2016. See also Lisa Ruth Rand, 'Falling Cosmos: Nuclear Reentry and the Environmental History of Earth Orbit', Environmental History, 24, 1 (2019), 78-103.

50 Perhaps ironically, even the US Department of the Interior participated in the Space Race: the department manages a satellite designed to search for mineral resources in outer space. See Megan Black, The Global Interior: Mineral Frontiers and American Power (Cambridge, MA: Harvard University Press, 2018), 183-213. On militarisation of space in a Cold War context, see Alexander Geppert, Daniel Brandau and Tilmann Siebeneichner, eds., Militarizing Outer Space: Astroculture, Dystopia, and the Cold War (New York: Palgrave Macmillan, 2021). See also Alexander Geppert, 'Rethinking the Space Age: Astroculture and Technoscience, 1900-1975', History and Technology, 28, 3 (2012), 219-23 and Alexander Geppert, 'Phantasie, Projekt, Produkt: Astrokultur und der Weltraum des 20. Jahrhunderts', Aus Politik und Zeitgeschichte, 69, 29/30 (July 2019), 19-25. 
also new opportunities for connection, with satellites performing some of the same functions in connecting Europe with the rest of the world that undersea cables or steamships had done previously. ${ }^{51}$

Thinking about 'ecosystems' has allowed some European historians to bypass conventional political and even geographic boundaries. Ryan Jones's study of the extinction of Steller's Sea Cow follows ships and men (and sea cows) between Russian Siberia and the Aleutian peninsula, but it begins with Rudyard Kipling's 'haunting sense of loss that extinction has left on colonial landscapes and seascapes', a lament that 'sits ill at ease with [Kipling's] well-known praise of the "White Man's Burden" and ultimate sanction of the British Raj's authority over humans and animals in India', suggesting that Kipling was attuned to the 'paradoxes provoked by the violence necessary to civilization'. ${ }^{52}$ Jones reorients border zones of Europe, in this case the border between Russia and Alaska, within a global history of colonialism, a history in which naturalists were more powerful as agents than as critics of imperialism. Jones's North Pacific creates its own coherence, 'following the boundaries that made sense to... natural historians' that stretched from Kamchatka to the Alexander Archipelago. ${ }^{53}$ A map of the northern hemisphere with the North Pole at its centre appears in Claudio Saunt, West of the Revolution, and invites readers to see global trade links connecting the Aleutian islands, Okhotsk, Yakutsk, Irkutsk and Kyakhta in Siberia to Arkhangelsk, St. Petersburg and London and to York Fort, Montreal and New York in the Americas. No division between Asia and Europe is discernible. ${ }^{54}$ The fur trade in the Bering Strait was a matter of life or death for aboriginal peoples like the Chukchi, Yupik and Inupiaq, but it also brought Alaska into Russian, British, US-American, Chinese and German history. ${ }^{55}$ Pey-Yi Chu's intellectual history of permafrost shows how Soviet science, systems thinking and the militarisation of the Arctic combined to reframe the understanding of the very ground. ${ }^{56}$ Recognising spaces defined by weather patterns, animal migratory behaviours, soil quality, ocean currents and other categories outside of politics has helped environmental historians see beyond the nation state - but it has also uncovered the ways in which imperialist and capitalist narratives hide the violence wrought by Europe's expansions.

Like Europe, the Middle East and North Africa is an abstraction unbounded by clear geography, a single polity or a uniform environment. ${ }^{57}$ And yet there have been creative efforts to make sense of it ecologically. Richard Bulliet's The Camel and the Wheel created a region of analysis around the breeding and use of camels for transportation, that is, a space defined by technology and human-animal relations. ${ }^{58}$ Timothy Mitchell's transformative chapter 'Can the Mosquito Speak?' linked technical

51 My thanks to Ben Goossen for suggesting this point. On Europe and space more generally, see John Krige, A History of the European Space Agency 1958-1987 (Noordwijk: European Space Agency, 2000); Asif Siddiqi, The Red Rockets' Glare: Spaceflight and the Soviet Imagination, 1857-1957 (Cambridge: Cambridge University Press, 2010); Colleen Elizabeth Anderson, “Two Kinds of Infinity”: East Germany, West Germany, and the Cold War Cosmos, 1945-1995', PhD Thesis, Harvard University, 2017; Benjamin W. Goossen, 'The Year of the Earth (1957-1958): Cold War Science and the Making of Planetary Consciousness', PhD Thesis, Harvard University, 2021.

52 Ryan Tucker Jones, Empire of Extinction: Russians and the North Pacific's Strange Beasts of the Sea, 1741-1867 (Oxford, 2014), 3.

53 Jones, 8, 12. Compare this to other studies of the region with a more Russian focus: Yuri Slezkine, Arctic Mirrors: Russia and the Small Peoples of the North (Ithaca, NY: Cornell University Press 1994); Paul R. Josephson, The Conquest of the Russian Arctic (Cambridge, Mass.: Harvard University Press, 2014); Paul Josephson, et al., An Environmental History of Russia (Cambridge: Cambridge University Press, 2013); John McCannon, Red Arctic: Polar Exploration and the Myth of the North in the Soviet Union, 1932-1939 (Oxford: Oxford University Press, 1998); Andy Bruno, The Nature of Soviet Power: An Arctic Environmental History (New York: Cambridge University Press, 2016).

54 Claudio Saunt, West of the Revolution: An Uncommon History of 1776 (New York: Norton, 2014), 38.

55 John Bockstoce, Furs and Frontiers in the Far North: The Contest among Native and Foreign Nations for the Bering Strait Fur Trade (New Haven: Yale University Press, 2009); Bathsheba Demuth, op cit.

56 Pey-Yi Chu, The Life of Permafrost: A History of Frozen Earth in Russian and Soviet Science (Toronto: University of Toronto Press, 2020); Pey-Yi Chu, 'Mapping Permafrost Country: Creating an Environmental Object in the Soviet Union, 1920s-1940s', Environmental History, 20, 3 (2015), 396-421.

57 Alan Mikhail, Water on Sand: Environmental Histories of the Middle East and North Africa (Oxford: Oxford University Press, 2012), 2.

58 Richard Bulliet, The Camel and the Wheel (Cambridge, Mass.: Harvard University Press, 1975), 3. 
expertise, capitalism, the chemical industry and militarism to the breeding zone of the mosquito and in so doing introduced the concept of the non-human actor certainly to me individually and arguably to my generation. ${ }^{59}$ Alan Mikhail's research on Egypt led him to conclude the Ottoman Empire was itself an 'ecosystem of collective dependence and determination', itself connected to global exchanges: 'a volcano in Iceland, rats in northern India, timber stocks across the Mediterranean, water buffalo in villages throughout Egypt ... must be brought into our analytical frame to properly understand the empire's history ${ }^{60}$ In recreating the Ottoman Empire as an ecological system with inputs and outputs on a global scale, however, it is all too easy to leave out Southeastern Europe. The boundary separating European history from the history of the Middle East and North Africa marginalises Southeastern Europe, the infamous 'Balkans', twice over.

Nor have Europeanists done any better in breaking down this barrier, despite all of the good intentions informing decades of research on the Mediterranean. This is not just a question of avoiding the kind of 'civilisational divide' ideology that has characterised studies of Europe and the Ottoman Empire from Pirenne to Huntington. Taking as an example the study of the plague, Nükhet Varlik shows that 'separate histories of plague in Europe and the Middle East-Islamic world' obscure the coherence of 'the plague experiences of Europe and the Ottoman world', which shared the 'unified microbial zone of the Mediterranean'. ${ }^{61}$ Like 'Europe' itself, though, the conceptual coherence of the Mediterranean has difficulty withstanding strict scrutiny. Peregrine Horden argues that the Mediterranean cannot be defined in terms of climate or botany. His collaborator, Nicholas Purcell, wryly noted, 'attempts to establish precise characteristics for defining what is Mediterranean have undesirable consequences'. ${ }^{62}$ In contrast, placing the Mediterranean in a global context reveals not only 'vineyards, silver-green olive trees and golden-yellow cereal fields' but also cypresses from Persia and cactus plants and tomatoes introduced after the Columbian exchange. ${ }^{63}$

Judith Tucker has linked the tension between Braudel's coherent Mediterranean and Horden and Purcell's collection of microecologies to larger debates about unity and conflict. ${ }^{64}$ The stakes in this debate can be high. It is no accident, writes Molly Greene, that the word Mediterranean is a 'Roman/Latin word, of Greek origin', with no resonance among the 'Muslims of North Africa and the Levant'. It is difficult to argue for the unifying power of a word that only half of the community it purports to create has any interest in using. 'In the most lethal use of "Mediterranean"-type thinking', Greene warns, 'French colonial officials fervently promoted Algeria's classical past as a way of turning their new conquest into a part of France. This connection between the word [Mediterranean] and European imperialism or, at the very least, Eurocentrism, is an anxiety that the field of Mediterranean history shares with Atlantic and Pacific history' despite the fact that 'one of the original motivations for the study of bodies of water was "to escape the restrictions of the nation-state"'. ${ }^{65}$ Braudel's original work argued for the unity of the lands around the sea as a coherent

59 Timothy Mitchell, Rule of Experts: Egypt, Techno-Politics, Modernity (Berkeley: University of California Press, 2002), 1953.

60 Alan Mikhail, Under Osman's Tree: The Ottoman Empire, Egypt, and Environmental History (Chicago; University of Chicago Press, 2017), 199.

61 Nükhet Varlik, Plague and Empire in the Early Modern Mediterranean World: The Ottoman Experience, 1347-1600 (New York: Cambridge University Press, 2015), 71.

62 Nicholas Purcell, 'The Boundless Sea of Unlikeness? On Defining the Mediterranean', Mediterranean Historical Review, 18, 2 (2003), 10.

63 Tabak, Waning of the Mediterranean, 299.

64 Judith Tucker, 'Introduction', in Tucker, ed., The Making of the Modern Mediterranean: Views from the South (Berkeley, Calif., 2019), 1-15.

65 Molly Greene, 'The Mediterranean Sea', 139; Alison Games, 'Atlantic History: Definitions, Challenges and Histories', American Historical Review, 111, 3 (2006), 744; and Patricia Lorcin and Todd Shepard, 'Introduction', in French Mediterraneans: Transnational and Imperial Histories (Lincoln: University of Nebraska Press, 2016), 1-18. Upon reading an earlier draft of this piece, Emile Chabal pointed out that although large bodies of water transcend the boundaries of the nation state, they don't necessarily transcend empire or imperial systems. 'This is particularly apparent in the French case', he explained, 'where coastal Algeria was formally integrated into the nation state, but Tunisia, Morocco and southern 
analytical space, promised to bridge the divide between Europe, Asia and Africa and to transcend the limitations of national categories. But Nabil Matar notes that Braudel's perspective on the unity of the Mediterranean transplanted a twentieth-century condition of 'European or European-sponsored mandate/colonisation' back onto the early-modern period. The very notion of connectivity, Matar stresses, is based on a 'European colonial conceptualisation of the Mediterranean' that 'completely ignored Arabic writings and Arab voices'. ${ }^{66}$ In a 2019 volume on The Making of the Modern Mediterranean highlighting 'views from the South', Tucker brought Ottoman, Arab and other North African voices into the chorus of tales told about the Mediterranean. But it is the eclecticism, rather than the geography, of Tucker's volume that is perhaps the best tribute to how European histories with a focus on nature and material culture, environments and climates, animals and disease, parks and recreation can engage the global turn. The 'rethinking of the tensions between space and place, and in particular how ways of perceiving and living in the physical Mediterranean were influenced by local, regional, and global contexts ${ }^{37}$ that her book offers could lead to the recognition that large parts of European history are not European at all.

That last sentence was, at one time, where this article ended. In the time that separated the first draft from this one, our planet entered a global pandemic. For many people - but notably not for all people - the pandemic brought about a simultaneous shrinking and widening of scales as well as a reshuffling of the social categories of intimacy and accessibility. In my own life, people I was used to seeing every day disappeared, new rules of socialising divorced from physical proximity encouraged me to reconnect with people I hadn't seen in decades. A long-lost friend, now a landscape architect, alerted me to an essay on pandemics by landscape designer Félix de Rosen. 'Pandemics are not works of art,' de Rosen notes. 'They are real, tragic events, occurring in the real, physical world'. Most people have, understandably, focused on what the pandemic has done to us, to human beings and our communities. De Rosen instead cites ecological writer Jim Robbins' 2012 article explaining that epidemics 'don't just happen. They are a result of things people do to nature'. ${ }^{68}$ They are, that is, embedded in both environmental and global history. De Rosen continues:

Human socioeconomic systems interact with the environment to create conditions that harbour and produce disease. Our contemporary systems are characterised by neoliberal capitalism, intensive resource extraction, and unceasing encroachment on wildlife habitat. Potential disease vectors like mosquitoes, ticks, and bats are most prevalent at the urban periphery, where human activity penetrates biodiverse ecosystems. It [is] on these peripheries that diseases are most likely to make the jump to humans. This, along with modern air travel, the intense growth of animal agriculture, and wildlife trafficking are all characters in our modern stories of pandemic. ${ }^{69}$

De Rosen's observations echo a longstanding European ecosocialist tradition, going back to the distinctive but complementary efforts of André Gorz and René Dumont in the 1970s to incorporate

Algeria were not. In French eyes, the Mediterranean transcended the (French) nation state, but not the (French) empire'. I welcome further discussion of this distinction.

66 Nabil Matar, "The "Mediterranean" through Arab Eyes in the Early Modern Period: From Rūmī to "White In-Between Sea", in Tucker, ed., The Making of the Modern Mediterranean, 17 and 18.

67 Tucker, Making of the Modern Mediterranean, 11.

68 Jim Robbins, 'The Ecology of Disease', The New York Times (14 July 2012), https://www.nytimes.com/2012/07/15/sundayreview/the-ecology-of-disease.html cited in Félix de Rosen, 'Europe's Last Plague', https://mcharg.upenn.edu/blog/storiesspace-times-quarantine (last accessed 25 June 2020).

69 Félix de Rosen, 'Europe's Last Plague', https://mcharg.upenn.edu/blog/stories-space-times-quarantine (last accessed 25 June 2020). 
an appreciation of the Earth's finitude into Marxist thought and simultaneously politicise ecology. ${ }^{70}$ Acute environmental disasters like Three Mile Island, Chernobyl or Fukushima; oil spills from the Exxon Valdez to Deepwater Horizon; the slower awakening to the never-ending problems of acid rain, the hole in the ozone layer, global climate change, irreversible polar melts and the so-called Anthropocene or sixth extinction have all been accompanied by a growing interest in environmental histories - histories that have, again and again, tied local disaster to global capitalism and its hierarchies of value(s). ${ }^{71}$

There is, of course, a certain irony in the global dimension of COVID-19. At some moments and from some perspectives, it seems people on every inhabited continent are experiencing some version of the 'same thing'. At other moments, and from other perspectives, this shared experience is profoundly different depending on a person's socioeconomic status, race, gender and position within a global economy created by imperialism. ${ }^{72}$ For many historians of Europe, our lives seem constrained, delimited to spaces smaller than the ones most of us usually inhabit: quite literally, our apartments. When I showed my friend Emily Greble this article, she laughed, 'we are now sitting at our kitchen tables barred from libraries and archives and yet seeking to make sense of the global scale of history'. Here, too, is a chance to foreground multiplicities of scale: scales of mobility, of community, of sacrifice. This pandemic offers the chance to revisit our understanding of how ecosystems are shaped, our attention to how racial capitalism and climate change intersect. May we all come through this safely, and wiser.

Acknowledgements. This article is dedicated to the memory of Stephen Anthony Walsh (1976-2018), whose dissertation, 'Between the Arctic and the Adriatic: Polar Exploration, Science and Empire in the Habsburg Monarchy' (PhD, Harvard University, 2014) found global connections in the most unexpected places. The author thanks David Blackbourn, Emile Chabal, Daphne Hazard Edwards, Aimee Genell, Ben Goossen, Emily Greble, Walter Johnson, Philipp Lehmann, Ian Miller, Dominique Reill, Carolin Firouzeh Roeder, Julia Adeney Thomas, Matthew Worsnick, Tara Zahra and the editorial team at Contemporary European History for suggestions on how to improve this article, not all of which I had the capacity to execute. Limitations, errors and omissions are, as ever, my sole responsibility.

70 For an overview of French ecosocialist thought, see Kerry Whiteside, 'French Ecosocialism: From Utopia to Contract', Environmental Politics, 6, 3 (Autumn 1997), 99-124. See also Kōhei Saitō, Karl Marx's Ecosocialism: Capitalism, Nature, and the Unfinished Critique of Political Economy (New York: Monthly Review Press, 2017); Sabine Mödersheim, Scott Moranda and Eli Rubin, Ecologies of Socialisms: Germany, Nature, and the Left in History, Politics, and Culture (Oxford: Peter Lang International Academic Publishers, 2019).

71 Matthew Sohm has shared with me a draft dissertation chapter that convincingly argues that the dioxin leak at Seveso, Italy, in 1976 should be added to this list.

72 Fernando Hellmann, Bryn Williams-Jones, Volnei Garrafa, 'COVID-19 and Moral Imperialism in Multinational Clinical Research', Archives of Medical Research, 51, 6 (Aug. 2020), 572-3; 'Decolonising COVID-19', The Lancet (May 2020), https://www.thelancet.com/journals/langlo/article/PIIS2214-109X(20)30134-0/fulltext; Nanjala Nyabola, 'Africa is not Waiting to be Saved from the Coronavirus', The Nation (11 May 2020), https://www.thenation.com/article/world/coronavirus-colonialism-africa/ (last accessed 24 Nov. 2020); Shirley Sze, Daniel Pan, Clareece Nevill, Laura Gray, Christopher Martin, Joshua Nazareth et al 'Ethnicity and Clinical Outcomes in COVID-19: A Systematic Review and Meta-Analysis', The Lancet, 12 Nov. 2020, https://www.thelancet.com/journals/eclinm/article/PIIS2589-5370(20)30374-6/fulltext, (last accessed 24 Nov. 2020)

Cite this article: Frank Johnson A (2022). Europe without Borders: Environmental and Global History in a World after Continents. Contemporary European History 31, 129-141. https://doi.org/10.1017/S096077732100028X 